\title{
District Assemblies in a Fix: The Perils of Self-Seeking Tendencies in Decentralisation Policy Reforms in Malawi
}

\author{
Blessings Chinsinga*
}

\begin{abstract}
This article appraises the prospects of the District Assembly system inaugurated under the auspices of decentralisation policy reforms introduced to institutionalise local governance structures and processes that are responsive, democratic, and capable of improving the livelihoods of the poor. While there seems to be reasonable consensus about the desirability of a decentralised planning framework as a vehicle for sustainable governance, development and poverty reduction, most stakeholders are nevertheless primarily motivated by the desire to advance, safeguard and gratify self-interests. Therefore, the major thrust of the argument of this paper is that unless these self-seeking tendencies are effectively tamed, the trinity of good governance, development and poverty reduction in the evolving structures and processes of local government will remain an unattainable ideal.
\end{abstract}

\section{Résumé}

Cet article aborde les perspectives du système des Assemblées de District inauguré sous les auspices des réformes de la politique de décentralisation, introduit pour institutionnaliser des structures et des processus de gouvernance locale réceptifs, démocratiques et capables d'améliorer les moyens de subsistance des populations démunies. S'il semble y avoir un consensus raisonnable sur le souhait de disposer d'un cadre de planification décentralisée pour servir de vecteur pour réaliser une gouvernance durable, le développement et la réduction de la pauvreté, il demeure cependant que la plupart des acteurs concernés semblent avoir pour préoccupation première la poursuite, la sauvegarde et la

* Department of Political and Administrative Studies, Chancellor College, P.O Box 280, Zomba, Malawi. E-mail: kchinsinga@yahoo.co.uk 
satisfaction d’intérêts personnels. Par conséquent, l’idée générale de l'argumentation dans ce papier est que tant que ces tendances égoïstes ne sont pas bien domptées, le triptyque bonne gouvernance, développement et réduction de la pauvreté dans les structures et processus dynamiques de la gouvernance locale restera une pure utopie.

\section{Setting the context}

Since the turn of the 1990s, the magnetic appeal of democratic decentralisation as a vehicle for good governance, development and poverty reduction has extended its reach to virtually all developing countries. International donors have particularly hyped the decentralisation of political responsibilities to local governments as a means of deepening and enhancing the prospects for sustainable good governance, development and poverty reduction. This is mainly the case because it is argued that decentralisation entails at least bringing government closer to the governed both in spatial and institutional senses (Blair 2000; Crook 2002; UNCDF 2002). The reforms leading to local governance are thus seen as providing a structural arrangement through which local people and communities can participate in the fight against poverty at close range (Boone 2000; Kauzya 2003; Heller 2001). The resultant institutional realignment thus opens up a whole range of possibilities for previously disadvantaged sections of societies as decentralisation facilitates efficient and responsive governance which leads to provision of services that timely respond to people's needs, expose corruption, enhance transparency and accountability, and ensure fairness. And, as such, decentralisation heralds a permissive and enabling atmosphere for communities to effectively realise their full potential for dignified and fulfilling lives (Mikkelson 1995; Varshney 1999; Chinsinga 2003).

However, decentralisation policy reforms in Malawi are not necessarily a recent phenomenon. The current efforts to restructure local government can best be seen as a continuous stream of transformative actions that can be traced back to the second half of the 1980s. To be properly and adequately understood, however, it is imperative to situate the present reforms in the broader context of the phenomenal political, economic and social transformation that Malawi has undergone in the recent past, especially following the collapse of Dr. Banda's Malawi Congress Party's (MCP) three decades of authoritarian one party rule in May 1994. Not only did it mark a disjuncture from the official rhetoric of institutionalised denial of crippling poverty but also stimulated unequivocally critical policy debates pertaining to poverty for the first time since independence (Anderson 1995 and Chinsinga 2002). This eventually culminated in the United Democratic Front (UDF) government adopting poverty reduction as its operative development phi- 
losophy. It thus clearly distinguished itself from its predecessor by placing poverty reduction at the centre of its overall economic and social agenda (Harrigan 2001 and Chinsinga 2003).

The collapse of the authoritarian state machinery was sealed with the adoption of a liberal democratic constitution in 1995 which, inter alia, guarantees a full range of civil, cultural, social, political and economic rights, democracy, good governance and the rule of law. It further recognises a viable system of local government as an integral building block of a functional and potentially vibrant democracy. Appropriate instruments, notably, the new local government Act, 1998, and the 1998 decentralisation policy, were promulgated in a bid to concretise the fundamental ideals embodied in the liberal democratic constitution. The ultimate objectives of these legal instruments are to build up local capacity, grassroots institutions and extraparliamentary arenas of participation. This means that it was only after the advent of democratic rule in May 1994 that local government restructuring became democratised both in terms of process and objectives.

Given Malawi's exceedingly pathetic socio-economic profile, characterised by marked polarisation between the rich and the poor, ${ }^{1}$ there is little doubt that the reforms propagated by the new government raised high hopes and enormous expectations especially among a populace reeling from three decades of one party dictatorship. The key question, then, is how have the decentralisation policy reforms spanning nearly a decade created an enabling atmosphere for sustainable governance, development and poverty reduction? This is certainly a very broad question but to begin to answer it, this paper takes a critical look at the prospects of the newly inaugurated District Assembly system (herein after DA) in institutionalising governance and administrative structures that are responsive, democratic and capable of transforming the livelihoods of the poor on a significant and sustainable scale.

The article is based on a qualitative semi-structured interview study that was commissioned by the Decentralisation Secretariat to assess the impact of the decentralisation process. The study takes 1993 as a benchmark for the assessment, since Malawi, as already stated above, has a very long history of decentralisation. ${ }^{2}$ The critical thrust of the findings of this study is that self-seeking tendencies widely prevalent among stakeholders in grassroots development present a major obstacle to the potential success of the DA system. Self-seeking tendencies have become a very serious issue mainly because the advent of democracy has created considerable space for manoeuvre that has led to the explosion of non-state actors in grassroots development, which for a long period of time was more or less an exclusive domain of the state. The non-state actors have included non-governmental 
organisations (NGOs), Community Based Organisations (CBOs) and donors. ${ }^{3}$ From less than ten NGOs in 1985 operating mainly in relief, health and education sectors, and often affiliated to church organisations, Malawi now has over 250 registered NGOs working in various fields such as empowerment, governance, participation, environmental degradation, economic governance and accountability in addition to relief, health and education sectors (Chirwa 2000 and Meinhardt and Patel 2003).

This dramatic increase in the number of NGOs has created an atmosphere in which a culture of self-seeking among the non-state actors is thriving, much to the detriment of the decentralised planning framework which is at the heart of the DA system. The main thrust of this culture is that stakeholders in grassroots development do not see each other as partners but rather as competitors, and yet a crucial dimension of NGO empowerment is the ability of NGOs to work together and share information in their efforts to promote sustainable governance, development and poverty reduction. There is, however, a strong desire among NGOs and donors to be the only organisation within a particular field and to be able to point to a demonstrable impact within the shortest time-period possible. In other words, the self-seeking culture among NGOs and donors borders on conflicts and struggles over influence, control and accountability.

This particular development is a cause of significant concern chiefly because coordination, cooperation and partnership among stakeholders in this sphere of endeavour are unquestionably key to policy effectiveness in order to achieve measurable success in governance, development and poverty reduction. The absence of these virtues often leads to the subordination of the broader policy goals to the pursuit of narrow and selfish interests. The paradox here, though, is that while there is seemingly reasonable consensus about the desirability of a decentralised planning framework as a vehicle for sustainable governance, development and poverty reduction, most stakeholders are on the contrary principally motivated by the desire to advance, safeguard and gratify self-interests. Therefore, the underlying argument of this paper is that unless these idiosyncratic tendencies are effectively tamed and systematically subordinated to the underlying noble cause of the decentralisation policy reforms, the trinity of good governance, development and poverty reduction will virtually remain an unattainable ideal.

\section{Decentralisation policy reforms in Malawi in perspective}

The official adoption of the constitution in 1995 providing for decentralisation was not Malawi's maiden attempt at decentralisation, but rather a culmination of a series of efforts which began with the colonial administrators as early as at the turn of the last century. However, the evolution of the existing 
local development planning structures predates by a couple of years preceding the country's return to multipartyism in May 1994. The need for reforms to the District Development Committees (DDCs), ${ }^{4}$ which ultimately laid the foundation for the present DAs, was first echoed in the 1987-1996 statement of development policies (GoM 1987). ${ }^{5}$ The major criticisms against DDCs were that they were: 1) hardly serious forums; 2 ) met irregularly; and 3) merely produced a series of wish lists for development projects. These could only be implemented if they were in line with the priorities of the central ministries. At least, for the first time since independence in 1964, the government officially acknowledged that Malawi's development track record, more especially at the micro level, was grossly erratic and, therefore, inconsistent with the official rhetoric which, almost negated the prevalence of poverty. ${ }^{6}$ This did not come as a surprise at all because the living standards of the country had substantially plummeted following the cumulative adverse effects of structural adjustment programmes (SAPs) adopted in 1981 in response to Malawi's chronic structural and fiscal imbalances as diagnosed by the IMF and World Bank (Chilowa 1999 and Harrigan 2001).

The most important catalysing factor for the reforms effected to the DDC institutional planning matrix was the publication of the joint GoM/UN Situation Analysis, which, for the first time ever, systematically compiled the official statistics regarding the incidence and magnitude of poverty in the country. This, inter alia, gave strong credibility to the contention that the DDC institutional framework was virtually ineffective for facilitating rural development in an effective and sustainable fashion (GoM/UN 1993; Kawonga 1994; UNCDF 1994). More importantly, the joint GoM/UN Situation Analysis marked a critical turning point in the official rhetoric of Dr. Banda's government, which either viewed poverty from a grossly minimalist perspective or negated its existence altogether. ${ }^{7}$

It is against this background that the Fifth GoM/UNDP ${ }^{8}$ Country Programme specifically targeted a reform of the rural development management regime. The underlying objective was to achieve a complete overhaul of the management regime in order to make it responsive to local needs and priorities as the people at the grassroots would be directly involved in the identification, design, implementation and management of projects and programmes. This would result not only in the equitable distribution of resources but also direct resources to areas where they were needed most. Poorer regions would catch up with those that were relatively prosperous, and there would be equal opportunity for all (GoM 1996 and Oyugi 1996).

The drive for renewed momentum in rural development culminated in the district focus policy initiative modelled on Kenya's experience in 1993. The 
substantial appeal of the Kenyan experience was perhaps aptly captured by Barkan and Chege (1989: 432) who characterised it 'as offering much for those who wish to learn more about the prospects for, and limits to, decentralisation in Africa'. The mainstay of the district focus policy initiative was to empower districts to plan and implement district specific projects that would otherwise be under the jurisdiction of the central government. The overarching aim was to make districts the focal points in the planning and implementation of district specific projects, hence transforming them into major forces and instruments for the design of rural development (Barkan and Chege 1989 and Oyugi 1996). This policy initiative was launched in six districts designated as Local Impact Areas (LIAs) ${ }^{9}$ in order to 'pilot participative, transparent, accountable and cohesive structures for planning, implementing and monitoring activities at district level' (UNCDF 1994: 8).

Several major changes were introduced within the framework of the DDC institutional planning matrix. A District Development Planning System (DDPS) and District Development Fund (DDF) were established to allow districts to prepare and implement their own projects (Kawonga and Lungu 1994; Anderson 1995; Oyugi 1996). The DDF entailed commitment by the central government to provide block grants to district authorities for small scale development projects such as improvements to feeder roads and water supplies, or the construction of community centres and health clinics, or the creation of income-generating projects identified by district residents and their elected representatives. The office of the District Development Planning (DDO) officer was also created. This was meant to strengthen the capacity of the DDCs to engage in planning and budgeting, since the office of the DDO served as a secretariat and repository of information for development planning and implementation in each district. The underlying rationale for the district focus policy innovation was that unless districts became financially autonomous, they could not assume a leadership role in matters of local governance and development. Whereas before the reform, MPs would devote considerable time to lobbying for their pet projects at the appropriate ministry headquarters in Lilongwe, they were now forced to conduct a greater proportion of such activities back in their districts by fulfilling their statutory role as members of DDCs. This would thus improve the public's access to the locus of decision-making since district institutions would play a greater role in the policy-making process.

The most significant change perhaps resulting from the adoption of the district focus initiative was the inauguration of the District Executive Committee (DEC). Its mandate was to serve as a technical or advisory body to DDCs (Anderson 1995 and Oyugi 1996). Prior to this transformation, all 
heads of line ministries and NGOs in addition to political and traditional leaders were members of the DDCs. The justification for the formation of DEC was that the ordinary members were not in a position to effectively contribute to the deliberations of the DDCs since technocrats dominated, and in most cases completely overshadowed them in development proceedings that were supposedly to be legitimately theirs'. The establishment of DEC, therefore, meant de-linking technocrats from the mainstream DDC.

The change of government in May 1994 did not in any significant way affect the underlying spirit of the reforms, but instead created an atmosphere in which the pace of the reforms was further harnessed and quickened. The membership of the DDC was, among other things, broadened to include cadres from the other political parties besides the then ruling party (MCP) in a bid to effectively reflect the plurality of interests in a multiparty political dispensation. The UDF government explicitly adopted poverty reduction as its operative development philosophy whose prime objective was to 'set up a responsive decentralised institutional framework that would promote community development which had been crippled by an entrenched top-down development strategy by the one party state' (GoM 1995: 13).

The efforts to promulgate a decentralisation policy framework benefited from the previous failed attempts. The process started in 1994 with a cabinet decision to review all decentralisation initiatives that had been undertaken in the country (Oyugi 1996; GoM 2001; Chinsinga 2003). This further benefited from study tours to countries such as Uganda, Ghana and Germany, which already had in place fairly well functioning systems of local governments. This was followed by broad based consultations with public and private stakeholders, political and traditional leaders and civil society, whose outcome was the 1996 draft national decentralisation policy (GoM 1998). The national decentralisation policy was effectively adopted in October $1998{ }^{10}$ This paved the way for the enactment of the Local Government Act in December 1998. The Act came into effect on 18 March 1999. The distinctive feature of the 1998 decentralisation policy was that it advocated devolution. The ultimate objective of the policy was to institutionalise real decision-making powers and authority in local jurisdictions with clear geographical boundaries, legal status and autonomous personnel to such an extent that a great bulk of their activities were substantially outside the direct control of central government.

Suffice to note here that DAs which were constituted following the November 2000 local elections retained almost wholesale the innovations introduced to the district planning framework under the auspices of the district focus policy initiative. The major change, however, arising from the consti- 
tution of the DAs was the merger of local councils and DDCs, which until then had essentially existed as distinct and parallel planning structures for grassroots development for almost three decades. The merger was imperative because it resolved an outstanding institutional paradox that enormously constrained the potential efficacy of each planning and administrative apparatus. The councils were legally constituted and yet were perpetually resource constrained, but while DDCs were richly endowed with resources, they were without legal or corporate status (Kaunda 1992; GoM/UNDP 1998; Chinsinga 2002). The activities of the DDCs were as a result insulated from legislative oversight or, indeed, any other kind of scrutiny, making them highly susceptible to abuse and patronage.

An interim administrative structure constituting the offices of the District Commissioner, Director of Administration and Director of Planning and Development was created in each DA following the merger of local councils and DDCs to oversee the implementation of the reforms in earnest. The underlying objective of the reforms, as stated elsewhere in the article, was to institutionalise participatory democracy and development anchored by a highly coordinated and decentralised planning framework. The rationale for such a planning framework was that synergies between stakeholders would create a favourable atmosphere for innovation and higher levels of productivity, as disconnected structures were weaved into a common framework at the local level. This planning framework, which was essentially a bequest from the district focus policy initiative, was established: 1) to provide a comprehensive resource profile of the districts to enable orderly planning, implementation and management of their own development; 2) to provide a coordinated system of development planning at the sub-national level; and 3) to ensure a systematic selection of projects for funding (GoM/UNDP 1998 and Gama et al. 2003).

To come up with a functioning and integrated decentralised planning framework, each DA is expected to institute a data bank, which in turn, serves as a springboard for developing Socio-Economic Profiles (SEPs) and District Development Plans (DDPs). The data banks are established on the basis of district-wide needs assessment using the participatory structures of the decentralised planning framework, which extends down to the grassroots. Coupled with macro-level district data, usually extracted from official statistics, the primary data gathered from communities are analysed and the product of this analysis is the SEP. The SEP details the status quo of development in the district, highlighting, among other things, its prospects and potential in various spheres of socio-economic endeavour. The SEP consequently forms the basis for articulating a DDP, which 'provides a compre- 
hensive but inherently flexible, pragmatic and adaptive policy direction and guidelines for the development of the district' (GoM/UNDP, 1998: 25). With a functionally robust and integrated decentralised planning framework, therefore, DAs would not only coordinate district level development initiatives with considerable facility but also be in a position to advise development partners which sectors and what areas in the district deserved priority consideration. The planning framework would further provide unity of direction and ensure that duplication in development initiatives was streamlined or minimised as much as possible. However, the possibility of creating a functionally robust and integrated decentralised planning framework is beset by difficulties, which, on the basis of the findings of the study upon which this paper is based, constitute the core of self-seeking tendencies.

\section{Self-Seeking tendencies: Paradoxes and realities}

Non-state actors, particularly NGOs, have grown dramatically since the close of the 1980s, a development that coincided with the current wave of democratisation sweeping across developing countries. Emerging as a democratic alternative to the highly discredited state-dominated social, economic and political development structures, NGOs now find themselves in a situation where local government structures are rapidly democratising, partly through decentralisation policy initiatives. The advent of democratic local governments has therefore created a challenging operating environment in which the success of NGOs depends very much on how they manage their external relationships with government, the private sector, other NGOs and with target communities.

Strikingly, both NGOs and local governments are motivated by the same policy discourse and goals. They both champion the participation of beneficiaries in development projects. The reasoning is that participation encourages the formulation of development strategies that are increasingly sustainable, people-centred and just. This handing back of decisions to the development beneficiaries leads to empowerment, loosely defined 'as making sure that people are able to help themselves' (White 2004: 8). It is thus a process in which individuals and organisations are supposed to gain control and mastery over socio-economic conditions, over democratic participation in their communities and over their stories (Fowler 1997 and White 2004). The ultimate objective is that beneficiaries of development interventions should develop awareness and control over the power structures that pervade and straddle development processes. Against this backdrop, the roles of NGOs in the quest for sustainable governance, development and poverty reduction are prescribed as follows: 
- Educate the public as to their rights and entitlements under government programmes;

- Attune official programmes to public needs by acting as a conduit for public opinion and local experience;

- Provide efficient and operational collaboration with government agencies and aid donors;

- Influence development policies of national and international institutions including support for decentralisation and local government reforms; and

- Help national and local governments to fashion a more effective development strategy through strengthening institutions and improving management capacity.

The roles of NGOs in sustainable grassroots development as prescribed above very much resonate with the underlying spirit of the decentralised planning framework. The fact that both local governments and NGOs are informed by the same development policy discourse bordering on democratisation, participation and empowerment potentially makes partnership and collaboration in their activities not a difficult venture - through the decentralised planning framework for example. The results of this study however show that such partnership and collaboration are fraught with considerable difficulties and challenges. These goals are not only difficult to realise between NGOs and local governments but also quite ironically amongst NGOs themselves. This invariably brings the interplay of self-seeking tendencies under the spotlight.

\section{Stakeholder circumvention of the decentralised planning framework}

The main finding of this study is that almost all NGOs and donors prefer to undertake their activities outside the evolving decentralised planning framework, often on the pretext of expediency, efficiency and effectiveness. The recurrent argument among the NGO and donor officials interviewed is that the decentralised planning framework is unduly constrained by, and often trapped in, frivolous bureaucratic procedures. While this argument cannot be merely dismissed, the major reason for this practice on the part of NGOs however concerns the differential operational procedures between local government on one hand and the NGO fraternity on the other. Most DA officials interviewed argued that while the overall goal of the decentralised planning framework is to cultivate a spirit of self-reliance among the grassroots, most NGOs mobilise communities with the help of financial inducements. 
It is therefore not surprising that DA officials consistently pointed out that the use of financial inducements has substantially diminished the appeal of participation within the framework of the participatory local government structures. Granted the precariousness of the livelihood patterns of the majority of the rural constituents, it was argued that they readily avail themselves of participatory development mobilised by NGOs rather than those mobilised through the local government structures. Supportive evidence for this tendency among the rural constituents was quite widespread in the course of the fieldwork, as for instance encountered at village in Mulanje DA. The people of Njema village undertook a comparative analysis of the NGOs and local government structures focusing mainly on resources, feedback and impact. Using OXFAM, which is very active in the area, as an example, they argued that NGOs are far superior to the local government structures. They observed that OXFAM does not only respond to problems presented to it very quickly but also rewards, at least in some way, all the people involved in the development projects. As such they are willing to participate in such projects for, in their view, 'it is not time completely wasted'. For those people who are in development management committees, the benefits are even quite substantial. They are exposed to several training workshops where they not only enjoy decent meals but are also paid out-of-pocket allowances.

Zeroing in on a school project within their locality, the people of Njema brought the limitations of the local government structures into the limelight against the backdrop of OXFAM's impressive track record. They argued that the school project took almost three years to get underway. Their major concern was that during this three-year period, no effort was taken to update them on the status of the project. Consequently, they were reluctant to engage themselves in development initiatives facilitated through local government structures, not only because the implementation of the projects was overly uncertain but also because there were virtually no immediate benefits associated with them. Given that the majority of the grassroots actually struggle for daily subsistence, it is obviously attractive and rational for them to readily turn to development endeavours with immediate benefits. The focus of the rural people is therefore almost exclusively on the financial benefits from projects rather than on the more philosophical goals of development as embodied in the NGO-local government participation and empowerment discourse.

The experiences of Nkhata Bay DA are very illustrative in this regard. Here, the use of financial inducements to court participation led to the birth of an NGO network called Umoza, which literally means unity. What prompted its formation was the experience of one of the NGOs in the DA - 
Africare - in one of its training workshops organised for district level officials and community members. The issue was that Africare did not give the participants any allowances but instead provided them with snacks. When delegates learnt that they would not be given any allowance, they demanded that the snacks be converted into allowances, arguing that other NGOs in the DA provided them with allowances and not snacks. The snacks were never eaten and since Africare did not have a budget line for allowances, the training session collapsed there and then.

The Umoza NGO network was therefore formed to provide NGOs in the DA with a forum where they could brief each other regarding their plans, successes and challenges. The issue of allowances was tackled but they reportedly failed to come up with a common operating framework. The proposal, according to the Africare official interviewed, was that they should come up with a uniform rate of allowances but 'we realised that it would not be possible because we have different and competitive policies'. According to most NGO officials interviewed in Nkhata Bay DA, the option to discontinue offering allowances altogether was out of the question because they are widely seen as 'a means of motivating people'. The compromise in Nkhata Bay DA according to the Africare official interviewed was that 'the allowances should be accompanied by a note explaining that it is the training that is more important than the allowances per se'.

The use of financial inducements has thus invariably turned into a tool that the NGOs are using to out-compete each other at two levels. NGOs are offering competitive financial inducements both to target communities and government extension agents. They are compelled to motivate extension workers financially because in most cases they use them not only as an entry point but also as a link with the communities with which they work. Since there are quite a lot of NGOs, communities as well as extension workers are reportedly more willing to support development initiatives of those NGOs that offer relatively attractive financial rewards. For example, the allowances given to communities, according to officials interviewed in Thyolo DA, range from MK 50 (Save the Children Fund (UK)); MK 250 (World Vision International); and MK 450 (OXFAM) [Note: 1USD is approximately 140 Malawian Kwacha]. This culture has in turn created a rural development market among both communities and extension workers with the highest bidding NGOs, especially as regards the extension workers, getting priority attention. This thriving rural development market has invariably created considerable confusion among the rural populace regarding the policy of the government on rural development, making development projects implemented through the decentralised planning framework extremely difficult to mobi- 
lise. This, as a matter of fact, deprives the decentralised planning framework of valuable opportunities that could be effectively exploited in order to support its progressive development and legitimacy.

Much as the drive toward decentralisation has been widely hyped and trumpeted by donors, the paradox is that they equally circumvent the decentralised planning framework. Most donors attributed their reluctance to operate through the decentralised planning framework to the fact that it does not yet have the requisite capacity to deliver the desired strategic impact. They argued that it is characterised by: 1) excessive bureaucratic delays in decision making; 2) weak accountability and transparency mechanisms; and 3) high labour turnover. Even more importantly they argued that operating outside the decentralised planning framework accords them the opportunity to fulfil their activities without undue political constraints. Their concern is that the lists of projects based on field and desk appraisals are rarely adhered to. Instead, it is power politics that ultimately determines how projects that have qualified for funding are actually allocated and distributed across DAs. These arguments are certainly to some degree plausible but according to the findings of this study they nevertheless mask the underlying credible reasons for sidestepping the decentralised planning framework.

The reality is that both NGOs and donor agencies are overwhelmed by self-seeking tendencies. According to DA officials interviewed, almost all stakeholders would like their specific labels attached to development programmes and poverty reduction initiatives that have directly benefited from their resources. It was therefore argued that it is hardly surprising that most donor agencies do not have specific policy documents clearly outlining their support and commitment to decentralisation. Here, particular reference was made to the European Union (EU) micro-projects and the Malawi Social Action Fund (MASAF). To argue its case, the Executive Director for MASAF pointed out that they have been forced progressively to expand their operating structures because of a lack of capacity in DAs. It has, for instance, in this regard increased zone managers for Community Sub Projects (CSPs) from nine to twelve; employed four zone managers for a Public Works Programme (PWP), which was essentially designated as an exclusive domain for DAs; and employed three regional managers for Sponsored Sub Projects (SSPs). The contention of DA officials is that most donors and NGOs are generally non-committal regarding decentralisation because the pool nature of the DDF funding mechanism would mean that no special credit would be attributed to them. Thus, under pressure to achieve a demonstrable impact or a set of objectively verifiable indicators, the stakeholders find it attractive to undercut the decentralised planning framework in order to create the space 
where they can expeditiously project their own institutional needs, perspectives and ideals onto rural communities. These would be lost if they functioned within the dictates of the decentralised planning framework.

There is little doubt that NGOs use the lack of capacity on the part of the DAs as an excuse for sidestepping the decentralised planning framework. Of course the fact that the capacity of this framework is weak is neither disputable nor debatable. This should not, however, be used as a pretext for debilitating it even further. The majority of the stakeholders as established in this study overlook the fact that 'it is conceptually normal to start from the point of weak local governance capacity and work towards strong local governance capacity' (Kauzya 2003: 13). This, indeed, makes sense if one views development as a progressive and qualitative movement from inability to ability, from incapacity to capacity. It is therefore hardly justifiable on the part of the stakeholders to hold out for a definite point in time when the decentralised planning framework shall fully attain the requisite capacity to serve as an effective vehicle for grassroots development. This means that if stakeholders continue to stand aloof, the decentralised planning framework will never acquire the desired stature.

The consistent use of the framework would substantially contribute to the steady and progressive development of the requisite capacity. The apparent lack of institutional capacity should not form an insurmountable barrier to the use of the decentralised planning framework. The danger is that holding back for as long as a standard level of capacity is absent amounts to condemning the institutional transformation to a virtual standstill. The fact is that capacity cannot just be legislated into existence; it has to be steadily built up. In fact, the most optimistic way to look at it is that the expanding scope of responsibilities implied by the decentralised planning framework may 'provide the incentive for public officials to invest in capacity building or seek creative ways to tap into existing sources of capacity' (Litvack et al. 1998: 27). The implications of the findings of this study are that all the stakeholders must look at the evolution of the decentralised planning framework as a process of capacity building of which they are an indispensable and integral part.

\section{The proliferation of NGOs and grassroots development: A blessing or a curse?}

The study further found that the number of NGOs operating outside both the decentralised planning framework and the national budget has exploded in the last three years. This is mainly a direct result of the suspension of the Poverty Reduction and Growth Facility (PRGF) macro-economic stabilisation initiative supported by the International Monetary Fund (IMF) in November 
2001 (Fozzard and Simwaka 2002). The suspension of the PRGF was triggered by overwhelming fiscal slippages which, inter alia, included: 1) diversion of donor resources to non-priority areas; 2) unbudgeted expenditures, notably external travel; 3) the disbursement of resources to the poor without a viable bureaucratic mechanism for accountability; and 4) a dramatic increase in official corruption and patronage. The financial base of the government has progressively contracted as a result.

The decision of donors to withhold budget support has inexorably led to the proliferation of international NGOs across the country, especially at DA level. It was for instance pointed out that donor agencies such as the Department for International Development (DFID), the European Union (EU) and the United States Agency for International Development (USAID) following the suspension of the budget support have expanded their establishments in an attempt to closely monitor the disbursement of their resources to the poor. The progressive expansion of their establishments notwithstanding, they are also sponsoring a lot of NGOs, which as a matter of practice, tend to operate outside the evolving decentralised planning framework.

The dramatic increase in the number of NGOs has also meant soaring levels of conflict, primarily around struggles for influence, control and accountability. In almost all districts, DA officials pointed out that NGOs have a tendency to over-concentrate their activities in a single area in a DA. This is often the case because NGOs are primarily interested in working with progressive communities, as they are not very concerned with investing in the institutional development of their target communities. This means that if a pioneering NGO in an area registers success in its programmes, new NGOs coming into the DA tend to flock into this particular one, often with similar kind of initiatives. An example of this scenario was provided in Mchinji DA. World Vision launched a seed multiplication project in Mulonyeni area in the DA which turned out to be a huge success. Within a very short period of time several NGOs invaded the area embarking on very similar projects. The use of financial inducements once again became a tool for the NGOs to get the attention of communities for they equally wanted to register successes within the shortest time-period possible by attracting progressive members of the communities. This unfortunately precipitated physical confrontation among community members belonging to different NGOs, allegedly fanned by the staff of competing NGOs in a bid to drive their competitors out of the area. DA officials further pointed out that the differential rates of financial inducements made the work of extension agents extremely difficult. The communities felt that the extension workers were playing some sort of game with the inducements, given the varied rates among the competing NGOs. 
The over-concentration of NGOs in a single area of DAs precipitated by the concern for control, power and influence means that DAs are often unable to effectively assess how various areas are being serviced, since these NGOs often venture there without the knowledge of the DA. The DA officials usually come to know about their presence when conflicts of this nature erupt. Against the backdrop of these developments an issue of significant concern in this article relates particularly to the limited scope of NGO activity to deliver the desired impact on the livelihoods of the rural constituents. NGOs are characterised by their small-scale and dispersed nature; they are frequently experimental and flexible, but in practice temporary and unstable (Osmani 2001; and Joshi and Moore 2002). The observations made by Deolalikar et al (2002) are particularly instructive in this regard. In Bangladesh, which holds the Asian record for the number of NGOs relative to the population, 'all NGOs taken together do not reach more than 20 percent of the rural poor' (Deolalikar et al., 2002: 33).

Granted that the primary objective is to create political capabilities among the poor not only on a substantial scale but also on a sustainable basis, the decentralised planning framework, with a nationwide coverage, offers a much more promising window of opportunity in this respect. A related advantage is that the decentralised planning framework potentially presents regular and predictable opportunities for citizen-state interaction. In sharp contrast, the key deficit on the part of the NGOs is that they are not legitimate objects of popular mobilisation in the way governments are (Joshi and Moore 2002). Moore and Putzel (1999: 5) perhaps aptly capture this dilemma:

It is legitimate in most political systems to criticize governments for failing to provide for the poor, or for performing badly. These concerns can be framed in terms of an accepted discourse of rights. It is not possible to do the same thing in relation to NGOs. They are not authorities against which rights can be asserted. There is even a need to ask who NGOs are accountable to, if indeed, they are accountable.

Moreover, a great many NGOs are susceptible to capture by elites at the expense of the grassroots they proclaim to serve, and as such their operations tend to be characterised more by the logic of rent than the logic of productivity. In Malawi, this assertion is particularly true with regard to what could possibly be characterised as the first generation NGOs, even though these realities are very much an integral part of the contemporary NGO scene also. Most of these NGOs were predominantly run by returning exiles. NGOs such as the Centre for Human Rights, Integrity and Justice, Women's Voice, Society for the Advancement of Women, Women's Voice and the Malawi Institute of Democratic Affairs among many others have 
actually disbanded. They have folded mainly because they were primarily used as a source of livelihood for the founders and not necessarily as vehicles for impacting on the livelihoods of the grassroots.

The case of the Malawi Institute of Democratic Affairs is particularly prominent in this regard. Within a year, its management failed to account for over US\$100,000 meant for civic education, small-scale development projects and mediation of conflicts among political parties, and could show no tangible output. Investigations indicated that the founder spent huge sums of money on international travel and telephone calls, lavish dinners and on various luxurious personal properties. As a result, the salaries of other employees could not be paid and the NGO accumulated crippling debts, forcing the founder to flee the country for South Africa.

A second major cause of concern arising from the proliferation of NGOs, especially in the wake of the suspension of the balance of payments support, is that the dominant players in this process are foreign nationals. This is a cause of concern because it substantially undermines prospects for the development of capacity for strategic policy analysis at the national and local levels. The failure of the majority of indigenous stakeholders to engage in informative policy analysis and advocacy, as is presently the case, often translates into lack of control over the development process. This is particularly critical for a country like Malawi whose public sector reform efforts are geared at creating viable DAs to assume a leading role in planning and implementing development initiatives. The proliferation of NGOs bolstered by enormous donor financial resources risks marginalising and debilitating the capacity of the evolving local government structures.

The planning framework, as envisaged in the decentralisation policy reforms, ideally portends an integrative avenue for at least systematically regulating the process of development at district level. The total disregard of the framework has more or less led to a state of institutional anarchy because a large number of donors interact unsystematically with a variety of governmental and NGO institutions to alleviate poverty. The inevitable consequences are an enormous waste of resources resulting from unnecessary duplication of activities, and the sheer lack of unity of direction. This makes the sustainability of these uncoordinated poverty reduction ventures doubtful especially when the whole range of interventions facilitated in this way would eventually become the responsibility of the DAs.

The impact of donors sidestepping government structures in their operations has already been felt by the government. In the aftermath of reflections over the 2004 budget, the Minister of Finance pointed out that the prospects for development have, inter alia, been hampered by the unorthodox operational strategies of most donor agencies. ${ }^{11}$ He argued that one of the chal- 
lenges facing the government, especially in the wake of the freeze on budget support, is that donors are funding sectoral authorities directly. The most critical issue, however, is that these expenditures are not in any way reflected in the national budget. The Minister argued that this mode of operation not only detracts from government planning but also makes its work extremely difficult. The key issue is that decentralisation should not be construed as meaning a laissez faire approach on the part of government but instead as demanding even greater control over the actors in the decentralised system of government. The stakeholders ought, indeed, to enjoy unfettered autonomy of operation but within the framework of standards regulated by the central government, especially in matters of strategic importance in the overall scheme of national development.

\section{Concluding reflections}

The study found that self-seeking tendencies are a critical obstacle in the institutionalisation of the decentralisation policy reforms in both LIAs and non-LIA districts. The official position on both NGOs and donors circumventing the decentralised planning framework is that it lacks the capacity to deliver the desired strategic impact. Quite surprisingly, NGOs are engaged in intense competition amongst themselves in which the use of financial inducement to mobilise communities and engage extension workers in their activities is the major driving force. This is apparently the hallmark of the interplay of self-seeking tendencies motivated by the strong desire to be the only organisation within a particular field, and to be able to point to the demonstrable impact of their activities, often within the shortest period of time possible.

Interestingly, both NGO actors and local government structures are predominantly informed by the same policy discourse and goals in their activities. Participation and empowerment of beneficiaries have become the standard cited objectives of both local governments and the non-state actors involved in grassroots development. On the face of it, it might not seem to matter a great deal whether local governments and non-state actors work in partnership or not. However, the limited coverage and the project nature of nonstate actors' activities make it imperative that some kind of working relationship is established between them and local government structures. The main appeal of the decentralised planning framework lies in its ability to reach almost every possible corner of the country, unlike most of the non-state actors whose spheres of influence tend to be localised often within the confines of urban and semi-urban centres. Besides, the decentralised planning framework presents a legally viable and predictable framework for interaction between rural communities and external stakeholders within the sphere 
of grassroots development. It could thus form the basis of institutionalised, and thereby sustainable forms of local participation.

The potential of the decentralised planning framework should be largely understood in the context of the principle of solidarity. This entails defining rules and the framework of cooperation between and among stakeholders at different levels of society (Scholz 2001 and Ikhiri 2001). The key argument here is that the activities of various stakeholders in so far as local governance, development and poverty reduction are concerned should not be taken as being competitive but rather as complementary. Taken in this way, the integrated decentralised planning framework would simply underpin the broad parameters that would create unity of direction among stakeholders, without being necessarily as rigid as feared by most stakeholders. There could, for instance, be a whole range of satellite organisations working on flexible terms with communities but tied at least in some way or another to the decentralised planning framework so as to ensure bureaucratic accountability and continuity.

\section{Notes}

1. The Gini-coefficient for Malawi, which measures the magnitude of inequality between the richest and the poorest quintiles of the population in a country, is estimated at 0.38. Malawi's Gini-coefficient is among the highest on the African continent.

2. The major objective of this study was to assess the impact of the decentralisation processes, focusing mainly on how the Decentralisation Secretariat and other stakeholders have impacted on the immediate level objectives at policy and institutional levels. This was mainly to achieve the following specific objectives: 1) to account for the efforts and resources spent on decentralisation in Malawi and to check the extent to which the objectives of decentralisation have been reached or not, and if not what are the reasons for non-achievement; and 2) to share results, particularly lessons learnt and best practices, with a wider community of stakeholders in the field of decentralisation. An attempt was made to include districts spanning the entire continuum of performance and comprising both Local Impact Areas (LIAs) and non-Local Impact Areas (non-LIAs). LIAs are those districts in which the ongoing decentralisation policy reforms were piloted under the district focus policy initiative. Nsanje, Mchinji and Nkhata Bay were included in the study sample as LIAs whilst Mulanje, Mwanza and Ntcheu represented non-LIAs. The idea was to assess whether there would be any discernible differences between these two sets of districts.

3. For the purposes of this paper a firm distinction is not made between NGOs and CBOs. All non-state actors excluding donors are loosely referred to as NGOs. 
4. According to Baker (1975), Malawi became independent with a local government system almost approaching the ideal. Its development was, however, negatively affected by the 1964 cabinet crisis in which there was an internal split between Dr. Banda and the young and progressive ministers over foreign and domestic policies. The intensity of the crisis was, among other things, blamed on the local authorities. To neutralise them, the government established, administratively, DDCs, to anchor rural development initiatives. The DDCs enjoyed more resources compared to the local authorities, even though the former were merely established by an administrative act. The preferential treatment of the DDCs over the local authorities gradually but steadily eroded their powers. For details see Baker, C. (1975) The Evolution of Local Government in Malawi, Ile-Ife, University Press.

5. The statement of development policies outlined strategies to be pursued in various sectors of the economy in order to achieve satisfactory economic, social, political and cultural progress. The first statement of development policies spanned 1971-1980 whilst the second one was operational from 19871996. Meanwhile, the ten year planning cycle has been overtaken by the vision 2020 planning innovation which seeks to chart the potential trajectories of development in all sectors of the economy whilst taking into account the aspirations, ambitions and fears of various segments of the population. The Malawi Grwth and Development Strategy (MGDS) has now taken centre stage as the guiding framework for governance, development and poverty reduction in the context of decentralisation.

6. The official position of Dr. Banda's government was that as long as the people had clothes on their back, enough food to eat, and lived in houses that did not leak, the question of poverty did not arise at all. Those in poverty had themselves to blame since they had attitude problems to hardwork. The implication of this was that economic success or failure was a consequence of nothing else but individual effort or lack of it respectively.

7. This particular study established the magnitude and severity of the problem of poverty in the country; the factors underlying its persistence; and the segments of the population hardest hit. The findings of the Situation Analysis pegged the prevalence of rural and urban poverty at 60 percent and 65 percent respectively. The population groups diagnosed as the worst hit victims included: smallholders with less than one hectare of land; estate workers; urban poor; female headed households; and children.

8. UNDP extends development assistance to Malawi in five-year cycles. Each cycle focuses on specific development issues. The fifth development assistance cycle, spanning 1992-1996, specifically targeted institutional and policy reforms in Malawi's development management and administration regime. A special focus was on the DDC institutional framework.

9. These are Nsanje, Thyolo and Mangochi in the South; Mchinji and Dedza in the Centre; and Nkhata Bay in the North. 
10. The objectives of the decentralisation policy are: to create a single structure at district level responsible for facilitating grassroots development planning and implementation; to overcome problems of coordinating development initiatives at district level since ministries had created their own structures; to promote popular participation more especially because the new constitution provides for good governance and development as rights; and to institutionalise participation as a strategy for poverty reduction following the adoption of poverty reduction as the operative development philosophy. Taken together, the decentralisation policy and the new Local Government Act seek to achieve the following objectives: to create a democratic environment and institution in Malawi for governance and development at the local level which will facilitate the participation of grassroots in decision making; eliminate dual administration (field and local government) at the district level with the aim of making public services more efficient, more economic and cost effective; promote accountability and good governance at local levels in order to reduce poverty; and mobilise the masses for socio-economic development at local level.

11. See ‘Donors Bypass National Budget', Daily Times, 30 July 2003.

\section{References}

Anderson, M, 1995, Case Study: Malawi Development Fund, New York: UNCDF.

Barkan, J., and Chege, M., 1989, 'Decentralizing the State: District Focus and the Politics of Reallocation in Kenya', Journal of Modern African Studies, 27, (3), 431-453.

Boone, C., 2000, 'State Building in the African Countryside: Structure and Politics at the Grassroots', Journal of Development Studies, 34, (4), 1-31

Blair, H., 2000, 'Participation and Accountability at the Periphery: Democratic Local Governance in Six Countries’, World Development, 28, (1), 21-39.

Chilowa, W., 1999, 'The Impact of Agricultural Liberalisation of Food Security in Malawi', Food Policy, 23, (6), 553-569.

Chinsinga, B., 2002, 'The Politics of Poverty Alleviation in Malawi: A Critical Review', in Englund, H., ed., A Democracy of Chameleons: Politics and Culture in New Malawi, Uppsala: Nordiska Afrika Institutet.

Chinsinga, B., 2003, 'The Participatory Development Approach Under a Microscope: The Case of the Poverty Alleviation Programme in Malawi', Journal of Social Development in Africa, 18 (1), 129-144.

Chirwa, W., 2000, 'Civil Society in Malawi’s Democratic Transition', in Ott, M., et al., eds., Malawi’s Second Democratic Elections, Blantyre: CLAIM.

Crook, R., 2002, Decentralisation and Poverty Reduction in Africa: The Politics of Local-Central Relations, Brighton,UK: Institute of Development Studies, University of Sussex.

Deolalikar, A., et al., 2002, Poverty Reduction and Role of Institutions in Developing Asia, Economics and Research Department Working Paper Series No. 18, Manila: Asian Development Bank.

Fowler, A., 1997, Striking a Balance, London: Earthscan. 
Fozzard, A., and Simwaka, C., 2002, How, When and Why does Poverty get Budget Priority? London: Overseas Development Institute.

Gama, J., et al., 2003, Linking the National and District Planning and Budgeting Systems, A Report Submitted to the Decentralisation Secretariat, Lilongwe, Malawi.

Government of Malawi (GoM)/United Nations (UN), 1993, Situation Analysis of Poverty in Malawi, Lilongwe, Malawi.

Government of Malawi (GoM), 1995, Policy Framework for Poverty Alleviation, PAP Coordinating Unit, Lilongwe, Ministry of Economic Planning and Development.

Government of Malawi (GoM)/United Nations Development Programme(UNDP), 1996, Decentralisation Policy Implementation: Capacity Assessment and Resource Needs Study, Lilongwe.

Government of Malawi/United Nations Development Programme (UNDP), 1998, Local Governance and Development Programme, Procurement Document, Lilongwe.

Government of Malawi (GoM), 1999, Decentralisation in Malawi: Status and Trends, Lilongwe, Department of Local Government.

Government of Malawi (GoM), 2001, Decentralisation Processes in Malawi: A Technical Cooperation Programme, Lilongwe: Decentralisation Secretariat.

Harrigan, J., 2001, From Dictatorship to Democracy: Economic Policy in Malawi 1964-2000, Aldershot: Ashgate.

Ikhiri, K., 2001, Thoughts on the Relationship between Traditional and Modern Power in Niger, Available at http://www.kas.org.za/Publications/ SeminarReports/Tradtionallocalparticipation/IKHIRI.pdf.

Joshi, A., and Moore, M., 2002, 'Enabling Environments: Do Anti-Poverty Programmes Mobilise the Poor?', The Journal of Development Studies, 37, (1), 25-56.

Kaunda, J., 1992, 'The Administrative Organisation and Processes of National Development Planning in Malawi', in Mhone, G., ed., Malawi at the Crossroads: The Postcolonial Economy, Harare: SAPES Books.

Kauzya, J-M., 2003, Local Governance Capacity Building for Full Range Participation: Concepts, Frameworks, and Experiences in African Countries, Discussion paper $\mathrm{N}^{\circ}$ 33. New York: United Nations.

Kawonga, A., and Lungu, P., 1994, A Study in Decentralised Cooperation in Malawi, A Report Submitted to the Department of Local Government, Lilongwe.

Litvack, J., et al., 1998, Rethinking Decentralisation in Developing Countries, Poverty Reduction and Economic (PREM), Washington DC: World Bank.

Meinhardt, H., and Patel, N., 2003, Malawi's Process of Democratic Transition: Analysis of Political Developments Between 1990 and 2003, Konrad Adenauer Stiftung: Montfort Press.

Moore, M., and Putzel, J., 1999, 'Politics and Poverty: A Background Paper for the World Development Report 2000/1’, Available at http://www.worldbank.org/ poverty/wdrpoverty/dfid/synthes.pdf. 
Mikkelsen, B., 1995, Methods for Development Research: A Guide for Practitioners, New Delhi: Sage Publications.

Osmani, S., 2001, Participatory Governance and Poverty Reduction, Available at http://www.undp.org/dpa/publications/choicesforpoor/ENGLISH/ CHAP05.PDF.

Oyugi, W., 1996, Mid Term Evaluation Report of the Programme IV: Management for Development for GOM/UNDP 5th Country Programme, Lilongwe, UNDP, Lilongwe.

Scholz, I., 2001, Promotion of Local Self-Governance in Africa as a Task of the Konrad Adenauer Foundation: Experiences and Prospects, Available at http:/ /www.kas.org.za/Publication/SemminarReports/Traditionallocalparticipation/ SCHOLZ.pdf

United Nations Capital Development Fund(UNCDF), 1994, 'Malawi Case Study', Available at http://www.uncdf.org/projects/reports/ldf-rev/con-cdf.htm.

United Nations Capital Development Fund (UNCDF), 2002, 'Poverty and Governance', A Paper Presented at the Fifth Africa Governance Forum (AGF V) Local Governance for Poverty Reduction in Africa, 23-25 May 2002, Maputo.

Varshney, A., 1999, 'Democracy and Poverty’, A Paper Prepared for the Conference on World Development Report 2000, World Bank, Available at http:// www.worldbank.org/poverty/wdrpoverty/dfid/varshney.pdf.

White, A., 2004, 'Is Empowerment the Answer? Current Theory and Research on Development Communication', The International Journal for Communication Studies, Vol. 66, No.1, pp 7-24. 